\title{
Interactive comment on "Characterization of Shallow Oceanic Precipitation using Profiling and Scanning Radar Observations at the Eastern North Atlantic ARM Observatory" by Katia Lamer et al.
}

Katia Lamer et al.

kxl5431@psu.edu

Received and published: 19 July 2019

Please see the supplement.

Please also note the supplement to this comment:

https://www.atmos-meas-tech-discuss.net/amt-2019-160/amt-2019-160-AC2-

supplement.pdf 